\title{
Monitoring and Characterizing Temporal Patterns of a Large Colony of Tadarida brasiliensis (Chiroptera: Molossidae) in Argentina Using Field Observations and the Weather Radar RMA1
}

\author{
Lourdes Boero $^{1,2, \dagger}{ }^{\text {, Denis Poffo }}{ }^{3,+}$, Verónica Damino ${ }^{2}$, Sabrina Villalba ${ }^{2}$, Rubén M. Barquez ${ }^{2}$, \\ Andrés Rodríguez ${ }^{4}$, Matías Suárez ${ }^{3}$ and Hernán Mario Beccacece ${ }^{5, *}$ \\ 1 Laboratorio de Ecología Evolutiva y Biología Floral, Instituto Multidisciplinario de Biología Vegetal, \\ Universidad Nacional de Córdoba, CONICET, FCEFyN, 5016 Córdoba, Argentina; \\ lourdes.boero@unc.edu.ar \\ 2 PIDBA (Programa de Investigaciones de Biodiversidad Argentina), PCMA (Programa de Conservación de \\ los Murciélagos de Argentina), Facultad de Ciencias Naturales e IML-Universidad Nacional de Tucumán, \\ 4000 Tucumán, Argentina; mdamino072@isep-cba.edu.ar (V.D.); vsabrina939@isep.cba.edu.ar (S.V.); \\ rubenbarquez@csnat.unt.edu.ar (R.M.B.) \\ 3 LRSR (Laboratorio de Radar y Sensores Remotos), Facultad de Matemática, Astronomía, \\ Física y Computación, Universidad Nacional de Córdoba, 5016 Córdoba, Argentina; \\ poffo@famaf.unc.edu.ar (D.P.); mes0211@famaf.unc.edu.ar (M.S.) \\ 4 Laboratorio de Hidráulica, Facultad de Ciencias Exactas Físicas y Naturales e IDIT, CONICET-Universidad \\ Nacional de Córdoba, 5016 Córdoba, Argentina; andres.rodriguez@unc.edu.ar \\ 5 CIEC (Centro de Investigaciones Entomológicas de Córdoba), 5016, Facultad de Ciencias Exactas, \\ Físicas y Naturales, Universidad Nacional de Córdoba, 5016 Córdoba, Argentina \\ * Correspondence: hernanbeccacece@unc.edu.ar \\ + These authors contributed equally to this work.
}

Received: 25 November 2019; Accepted: 30 December 2019; Published: 8 January 2020

check for updates

\begin{abstract}
Migratory colonies of up to thousands or millions of Brazilian free-tailed bats (Tadarida brasiliensis) are present in temperate areas of America. The monitoring of these massive colonies is crucial to know their conservation status and to evaluate the important ecosystem services that they provide. The objectives of this study were to characterize and to monitor, with an interdisciplinary approach, one of the largest bat colonies in South America, located in La Calera (Córdoba, Argentina). This study includes eight years of field observations inside of their shelter and outside when the colony emerged. Moreover, these observations were complemented with one year of weather radar detections using the Radar Meteorológico Argentino 1 (RMA1). To determine if a detection is a true or false massive emergence of bats, an algorithm was designed. We observed that this large colony of T. brasiliensis is maternal and migratory, just like others in South and North America. This colony arrives in early spring and births occur two months later, migrations occur in early autumn, meanwhile the shelter is empty or inhabited only by a small group of individuals during the cold seasons. The colony was estimated at 900,000 individuals before births occurred. The radar detection was coincident with field observations, when a simultaneous emergence was observed, as well as in the monitoring throughout the year. This represents the first study made in South America using radar technology for monitoring a bat colony. We here demonstrate that RMA1 is a powerful tool for monitoring this colony in the long term, and even to alert possible changes in permanence in time or in the number of individuals.
\end{abstract}

Keywords: weather radar; bats; maternal colony; South America; Argentina; migration; aeroecology 


\section{Introduction}

Monitoring and characterizing of temporal and spatial patterns of animals with high mobility are necessary for their effective conservation [1-3]. These studies become more important when the species involved, such as bats (Mammalia: Chiroptera), provide ecosystem services [4]. These animals have long been postulated to play essential roles in agriculture because they can offer diverse benefits humans, i.e., suppression of arthropod pests, seed dispersal, and pollination [4-6]. For these reasons, bats can also be used as bio-indicators because they can reflect the status of plant populations [7]. Nonetheless, these animals have gained a bad reputation as potential sources of zoonotic diseases, such as rabies, severe acute respiratory syndrome (SARS), and ebola, and consequently they are often persecuted and killed [8,9]. However, the emergence of zoonotic diseases from bats seems also to be a consequence of anthropogenic modifications of natural environments [10]. Therefore, monitoring bat populations, and even more importantly, massive colonies in rural and urban systems, is crucial to know the conservation status of the species, study their behavior and ecology, analyze their efficiency as natural biological predators of agricultural pest insects, and to prevent diseases to humans [2].

The Brazilian free-tailed bat Tadarida brasiliensis (I. Geoffroy, 1824) (Chiroptera: Molossidae) is a medium-size species widespread in America from $46^{\circ}$ North latitude to $52^{\circ}$ South latitude [11,12]. This interesting species plays an important role in reducing populations of arthropod pests, thereby providing an important economic benefit to farmers [4,13]. Shelters are fundamental to bats because they are used for nesting, breeding, and interaction among individuals. This species uses a great variety of shelters, both natural (caves and hollow trees) and artificial (bridges, buildings, mines, tunnels, and culverts), in rural and urban environments, and they can take shelter solitarily, in small groups, or in large colonies of several millions of individuals [14]. Large colonies of this species have been reported at borders of their distribution, between the United States and Mexico in the northern hemisphere, and in Argentina, Brazil, and Uruguay at the southern hemisphere [15-20]. Those colonies are migratory and most of them are maternal. They are less common in South America than in North America where they have been very slightly studied [17,21]. Particularly in Argentina, there are three important known colonies: one at the Dam Escaba (Tucumán Province) in the northwest region, as well as two others in the central region at the Law Faculty, National University of Rosario (Rosario, Santa Fe Province) [17], and La Calera (Córdoba Province) in a limestone mining deposit.

There is an important potential in using radar technology for biological studies, quantifying animal movements, analyzing population densities and diversity, as well as for studying species phenologies across a wide range of spatial, temporal, and climatic scales [22,23]. This type of remote sensing tool is useful for studying birds, insects, and bats which fly in large groups at high altitudes [24-31]. It has been previously shown that weather radar detects movements of bat colonies, including T. brasiliensis [26,30-33]. These observations also show interactions between these highly mobile predators and their migratory insect prey [34]. Nevertheless, all known studies using radar technology on T. brasiliensis have been made in North America. Due to the size of the colony from La Calera, it can be detected by the weather radar "Radar Meteorológico Argentino 1" (RMA1) when bats emerge to forage. To complement information provided by the RMA1 with observations collected at the field could be extremely valuable to understand some behavioral aspects of this colony. Having better knowledge about these large colonies is fundamental to evaluate the ecosystem service that they can provide and most importantly to implement conservation strategies [35]. The aim of this study is to characterize and to monitor the colony of T. brasiliensis present in the locality of La Calera using field observations and weather radar detection with RMA1.

\section{Materials and Methods}

\subsection{Study Area}

The colony of Tadarida brasiliensis is housed in tunnels of the old and abandoned concrete factory "Hercules" (see Figure 1), inside a limestone mining deposit, in La Calera, Córdoba Province, Argentina 
(31.319S, 64.332W). The surrounding landscape is a semiarid savanna with typical vegetation of Chaco Serrano and Espinal [36]. The average monthly rainfall is $70 \mathrm{~mm}$, with markedly summer distribution $(140 \mathrm{~mm})$. The average annual temperature is $17^{\circ} \mathrm{C}$, with a maximum annual average of $24^{\circ} \mathrm{C}$ and a minimum annual average of $11^{\circ} \mathrm{C}$.
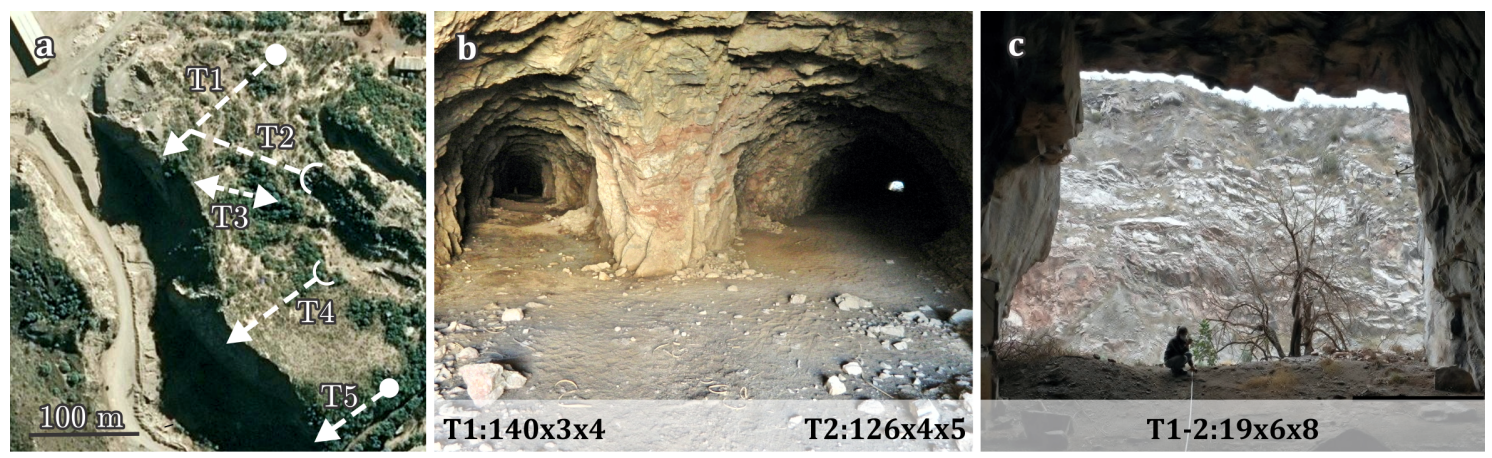

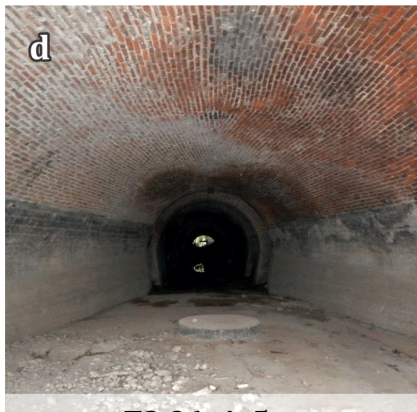

T3:96x4x5
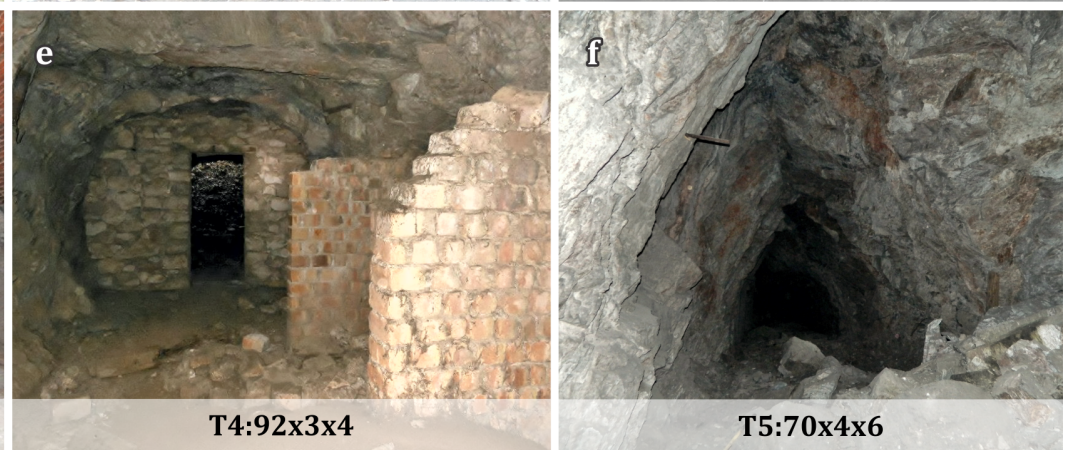

Figure 1. (a) Position of the tunnels (T) inside the old concrete factory. The ends of each tunnel are marked to denote whether they are open (arrowhead), partially obstructed (semicircle), or completely obstructed (full circle). (b,d-f) Each tunnel and their dimensions in metres (length, height, width).

(c) Section of the tunnels that connects $\mathrm{T} 1$ and $\mathrm{T} 2$, and their dimensions.

\subsection{Characterization and Monitoring of the Colony}

All tunnels were surveyed to record their geographic positions and dimensions (summarized in Figure 1a). Bats were captured and identified following Barquez and Díaz [37], by direct observations, photographs, and even traces (feces). The tunnels were visited 24 times from 2012 to 2019 in order to determine the composition of the colony, and periods of permanence and migration. The observations were made inside and/or outside the tunnel when the colony emerged.

The presence of the colony was verified and the following stages of bat-life were identified by observation: newborn pups (with no flying ability and hairless), young individuals (erratic flight and gray hair), and adults (normal flight and brown hair). Photographs with metric reference were taken before that births occurred, to obtain a preliminary estimation of the size of the colony. The number of individuals in a known area was counted and this value was extrapolated to the total area occupied by the colony [18]. Outside of the shelter, the onset time of the emergence was recorded as that when bats starting to emerge in large numbers [38], and it was compared with sunset time. The ending time of emergence was registered when the massive emergence was interrupted and bat emergence was observed in isolated groups. As additional data, birds of prey were recorded hunting the bats during the emergence. It is worth highlighting that no anesthesia, euthanasia, or any kind of animal sacrifice were used in this study.

\subsection{Radar Meteorológico Argentino 1 (RMA1)}

A weather radar is an instrument used to detect and characterize storms and other meteorological phenomena. The radar antenna emits pulses of radiation to targets under observation which intercept 
and scatter part of the pulse energy. This received signal or echo is amplified, digitized, and processed in the radar receiver, so it can be displayed and recorded. The time elapsed between the emission and the back-scattered signal reception is used to determine the target range since the pulses move at the speed of light [39]. The RMA1 is a C-band polarimetric Doppler radar located at the campus of the National University of Córdoba, Argentina (31.441S, 64.191W). The radar emits both horizontal $(\mathrm{H})$ and Vertical $(\mathrm{V})$ polarizations simultaneously, allowing the calculation of 3D fields of several variables or parameters: horizontal $\left(Z_{H}\right)$ and vertical reflectivity $\left(Z_{V}\right)$ factors in dBZ (decibels of $Z$ ), radial velocity $\left(V_{D}\right)$, spectral width $(W)$, differential reflectivity $\left(Z_{d r}\right)$, differential phase $\left(\phi_{d p}\right)$, specific differential phase $\left(K_{d p}\right)$, and correlation coefficient $\left(\rho_{h v}\right)$. The coverage radius of successive volumes is $240 \mathrm{~km}[29]$.

\subsection{Radar Sampling Data}

Bat observations using RMA1 were made from July 2018 to June 2019. During this period, radar strategies with a gate resolution of $450 \mathrm{~m}$ and 15 elevation angles were used for detection. The sampling time interval used was from 20 to $22 \mathrm{~h}$ Local Time (LT), generating on average 14 samples per day, collecting between 400 and 450 images monthly. The shelter of the colony is approximately $19 \mathrm{~km}$ away from the radar and at an azimuth of 316 degrees. Figure 2 shows the elevation profile of the terrain through a vertical slice in the azimuthal direction of the shelter and different elevation angles recorded by the radar plan position indicators (PPIs).

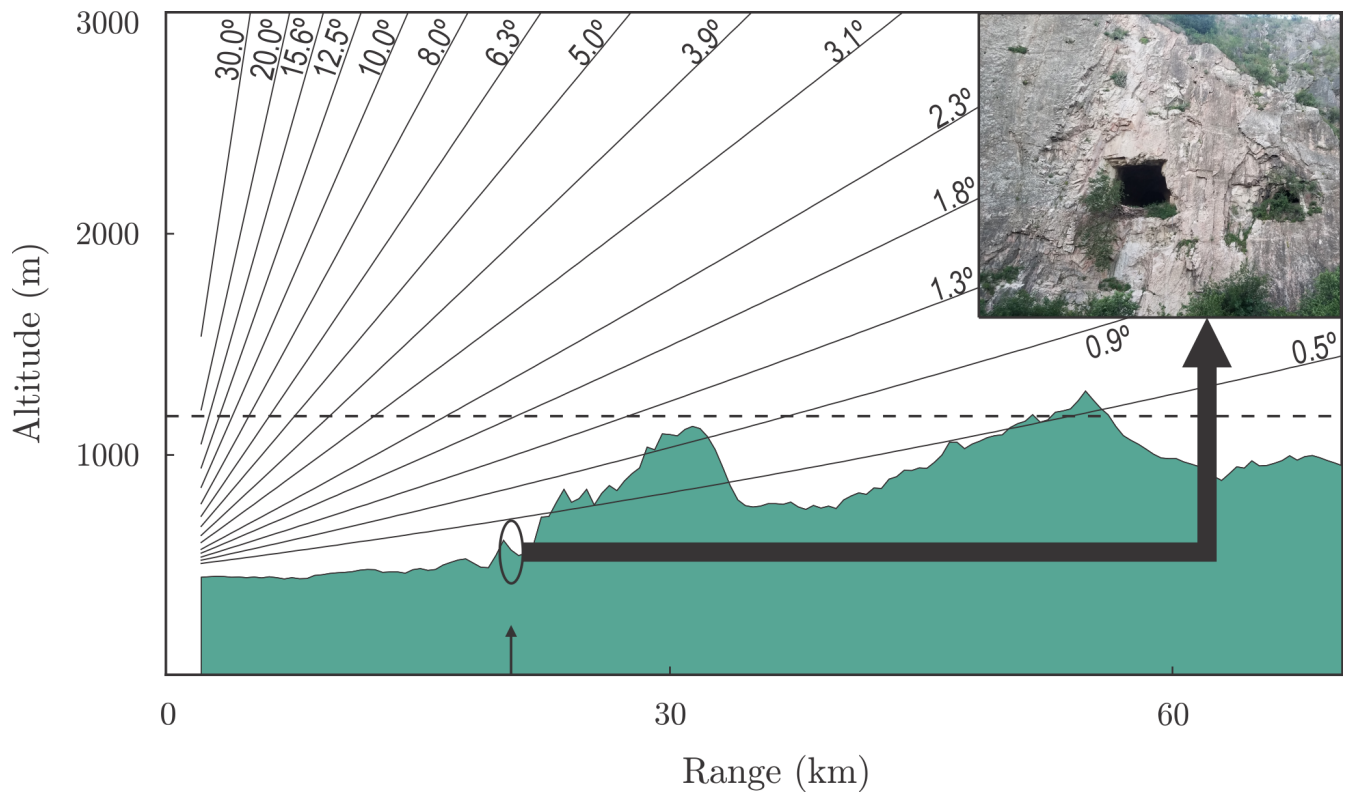

Figure 2. Description of the elevation profile of the land in the direction of the shelter, this last marked with an arrow and an oval. The elevation angles of the radar are described in solid black lines and a photograph of the outside of the common portion between tunnels 1 and 2 is shown. The horizontal black dashed line shows the height at which the observation is made (see intersection with plan position indicators (PPI) 4 (line 1.8 degrees).

The data sampling area was determined by taking the event that occurred on 15 December 2018, as the reference pattern. The sampling area is set between azimuths 305 to 328 and between $13 \mathrm{~km}$ to $21 \mathrm{~km}$ away from the radar, as shown in Figure 3. This figure shows in both images the horizontal reflectivity factor $Z_{H}$, associated with PPI 4, of the colony for 15 December 2018, at 20:39 LT. The image in the left panel shows data before filtering, while the right panel shows data after filtering as explained below. 

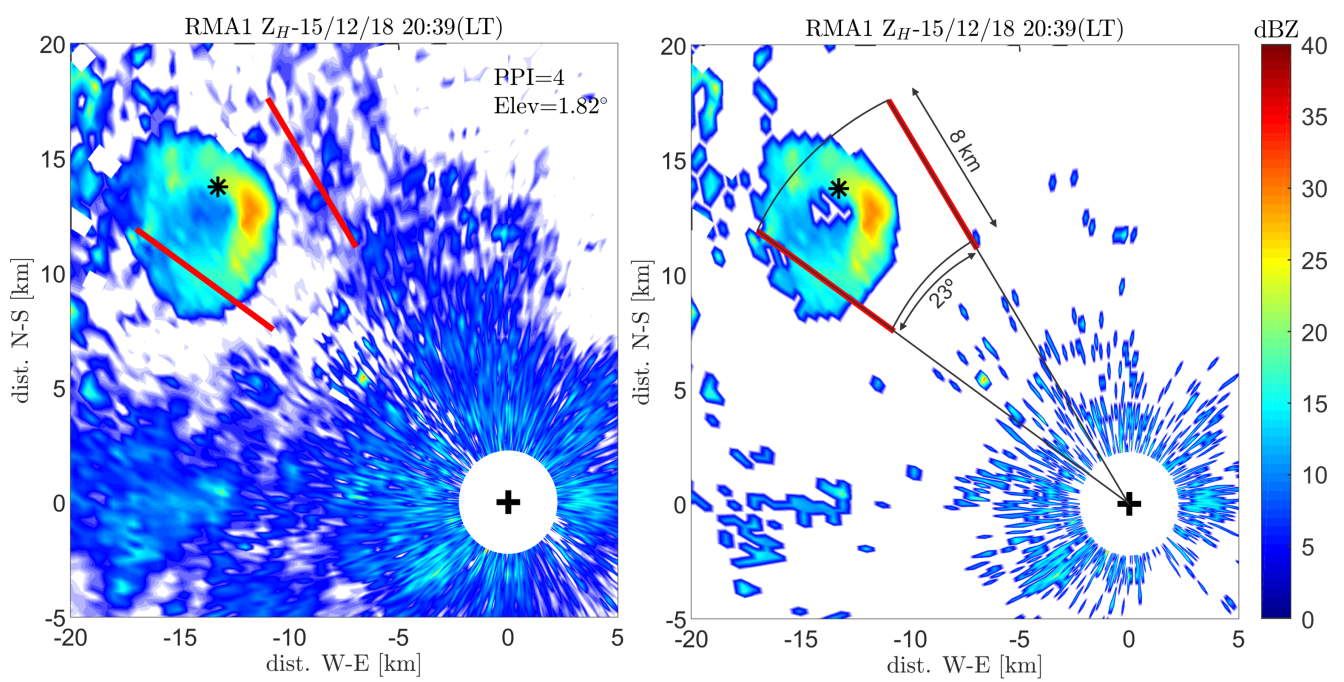

Figure 3. Horizontal reflectivity factor $Z_{H}$, associated with PPI 4, of the colony for 15 December 2018, at 20:39 LT. The image in the left panel shows the data before being filtered. The image on the right panel shows the filter applied to the data. Symbols indicate the position of the radar (plus) and the shelter of the colony (asterisk) and red lines delimit the sampling area.

\subsection{Bat Detection}

The method used to determine when a valid detection occurs is based on an algorithm that has to take into account three main factors: clutter echoes, meteorological echoes, and weak echoes.

The analysis performed on 15 December 2018, shows that the maximum reflectivity factor is close to $30 \mathrm{dBZ}$ for both the vertical and horizontal channels, as can be seen in Figure 4 . This figure also exposes the level of noise floor that may contain the information associated with detection. This criterion determines the first stage of the detection algorithm and is based on filtering the $Z_{H}$ and $Z_{V}$ data (if $Z_{H, V}>40 \mathrm{dBZ}, Z_{H, V}=N a N$ and if $Z_{H, V}<10 \mathrm{dBZ}, Z_{H, V}=0$ ).
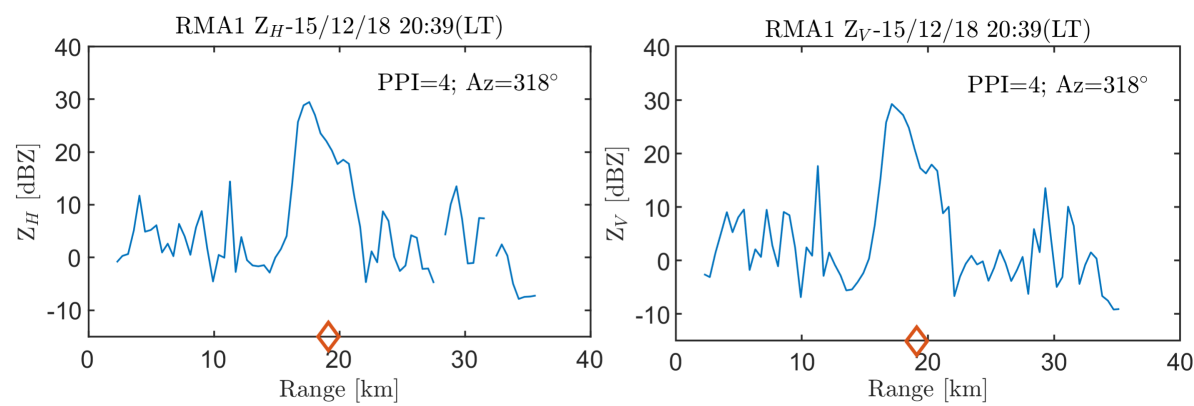

Figure 4. Reflectivity factor for both the horizontal $\left(Z_{H}\right)$ and vertical $\left(Z_{V}\right)$ channels as a function of distance to radar (range) for azimuth of $318^{\circ}$. The red rhombus marks shelter position.

The difference of $Z_{H}$ and $Z_{V}$ (in linear scale) whose relation is called $Z_{d p}$ was used to eliminate meteorological echoes. This factor was very useful to discriminate precisely, due to the characteristics that bats have when way out, the difference between a meteorological and non-meteorological echo. The $Z_{d p}$ factor for a meteorological echo will always be positive due to the characteristics of the hydrometeors that are in the atmosphere at heights to which the observation is performed. For the particular case of bats, the $Z_{d p}$ factor, within the area of analysis, shows a mixture of values between positive and negative, as can be seen in the right panel of Figure 5. Using this concept, a series of filters were created to validate a detection. The diagram in the left panel of Figure 5 shows the designed algorithm, Filter_1, applied in the sampling zone after calculating $Z_{d p}$. In this filter, it is established that all values between -1 and 1 are not significant for detection and therefore are replaced by $\mathrm{NaN}$ values. Filter_2 analyzes the density of negative points inside the sample, and if this value is less 
than $5 \%$ of the sample it is defined as false (take into account that during the emergence of the colony, $\mathrm{Z}_{d p}<0$ ). Filter_3 takes the difference between maximum and minimum values of the sample and compares it with the threshold obtained from the reference sample (15 December 2018). If this value is above the specified threshold, it is differentiated as a false detection because it is considered like meteorological data. Filter_4 analyzes the amount of $\mathrm{NaN}$ elements in the sample and if these exceed $90 \%$, it is defined as false detection. When detection is true, the maximum value of the variable $Z_{v}$ within the sample is assigned to that instant.
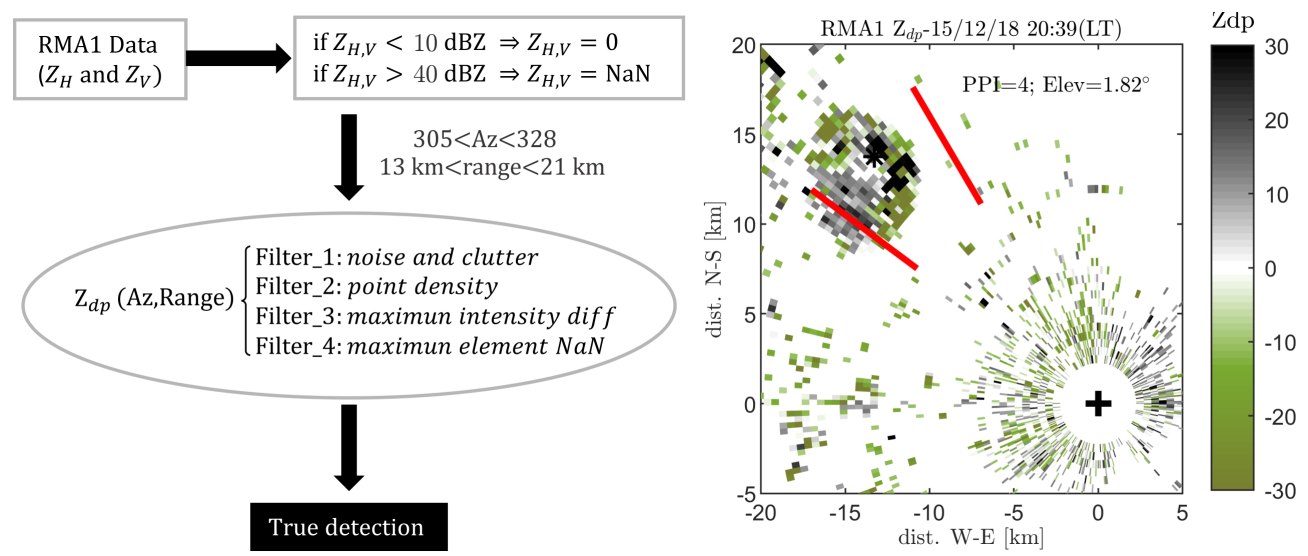

Figure 5. Sequence of filters that determine the algorithm used to validate a detection in the left panel.

The right panel shows the behavior of the variable $\mathrm{Z}_{d p}$ for a valid detection.

The behavior of the algorithm in the case of a sample contaminated by a storm is shown in Figure 6. This figure shows how regions with higher values than $40 \mathrm{dBZ}$ in the storm are eliminated. The remaining values are used to calculate $Z_{d p}$. This variable is presented in the right panel of Figure 6 . Here, most of the values that agree with the storm are always positive, however, within the sampling area there are some negative values that, depending on its characteristics, the algorithm will decide if the observation corresponds to a valid detection.
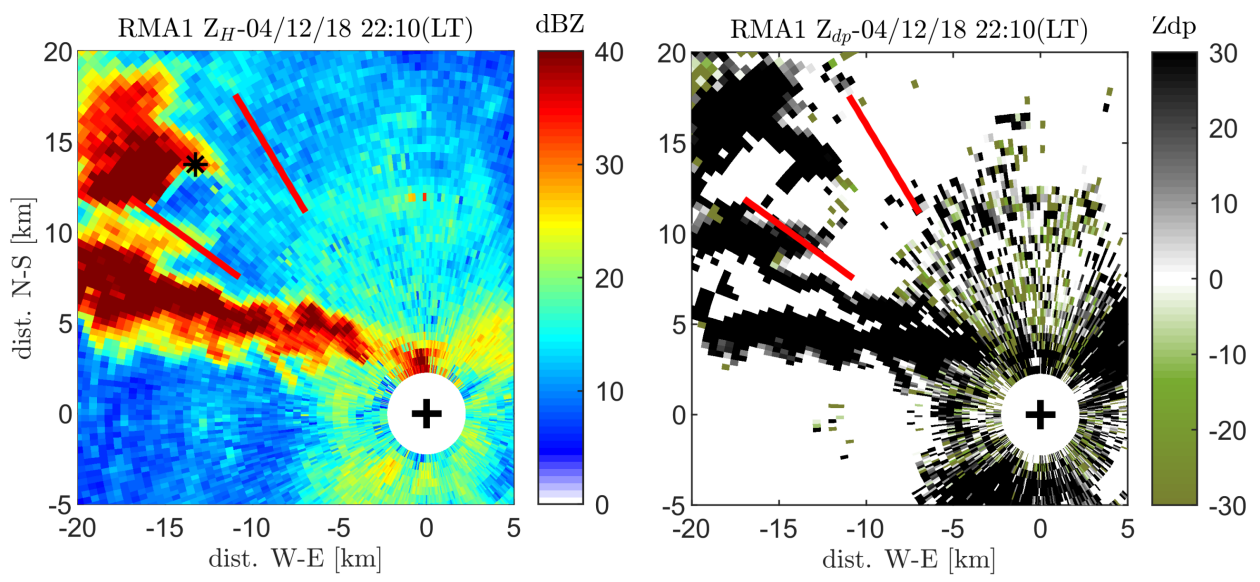

Figure 6. Storm detected on 4 December 2018 close to the observation area of the colony. The right panel shows the intensity of it using $Z_{H}$ for the PPI 4, while the left panel shows the output of the data after using the detection algorithm.

\section{Results}

\subsection{Characterization and Monitoring of the Colony}

The bats observed in the five tunnels belong to four species, including that of the large colony of Tadarida brasiliensis. This colony was housed in tunnel 2 where the floor was covered by a thick layer 
of guano. In tunnel 1, despite being connected to tunnel 2, no individuals were observed but a few deposits of guano were observed. Tunnel 3 was inhabited by one to 62 individuals of Histiotus sp. (Vespertilionidae), one or two individuals of Myotis dinellii (Vespertilionidae), and an individual of Desmodus rotundus (Phyllostomidae). In tunnel 4, visited only once, two individuals of $M$. dinellii and one T. brasiliensis were observed. Finally, in tunnel 5 there were 10 to 15 individuals of D. rotundus and the typical feces of hematophagous bats were observed.

Seasonal variations were observed in the colony of T. brasiliensis due to migration and births that occurred during their permanence in the shelter (Figure 7a-f). This colony arrived in early spring, between September and October. From the time of arrival until mid-November only adults were observed. Newborn pups were observed from late-November to mid-December, indicating that births occurred approximately two months after the arrival (i.e., the colony arrived in October but newborn pups were observed only by mid-December). It is worth noting that newborn pups were observed forming groups among adults (Figure 7c). The newborns were small, hairless, and incapable of flight (Figure 7e), but 45 days later were bigger with their bodies partial or totally covered with greyish hair, and capable of an erratic flight (Figure 7f). The large colony was recorded until mid to late April and since May after migration the number of individuals was considerably reduced. Finally, until the return of the colony, either no individuals or a small group of approximately 500 to 1000 individuals were observed (Table 1). The colony size was estimated at about 900,000 individuals and occupied an area of $450 \mathrm{~m}^{2}$ before the births occurred (October 2013).
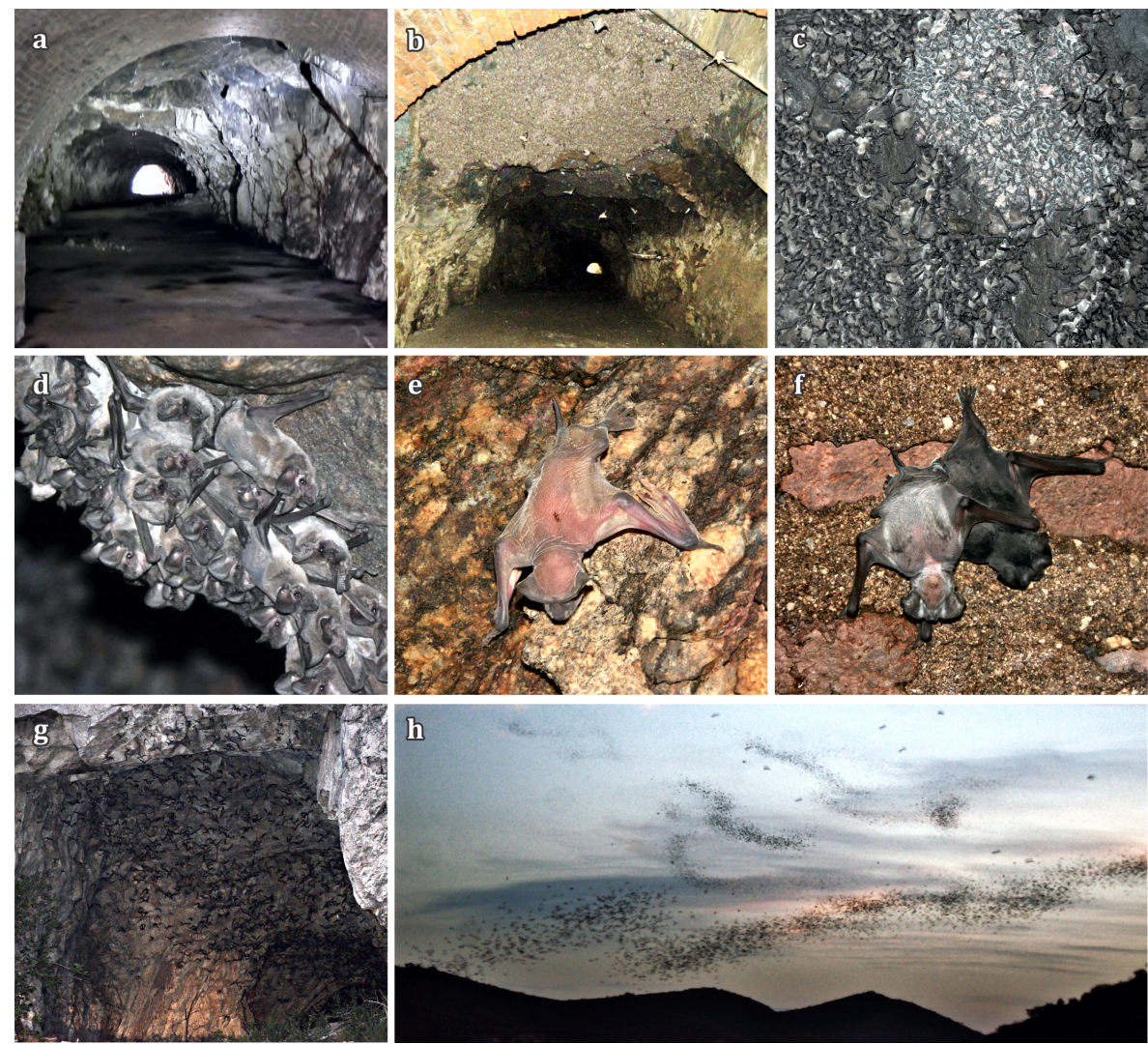

Figure 7. Colony of Tadarida brasiliensis. (a) Aspect of the shelter after migration (13 May 2014) and (b) after the return (30 November 2017), (c) bats crowded, the pale colored sector belongs to a group of newborn pups (30 November 2017), (d) group of adults (9 December 2014), (e) a newborn (30 November 2017), (f) two juveniles with different degree of hair coverage (January 27, 2014), (g) the emergence of the colony from the common portion of tunnel 1 and 2 (7 December 2018), (h) mass emergence as a continuous serpentine stream (21 January 2012). (Photo credits: S. Villalba-a, d, and g; L. Boero-b, c, e, and f; V. Damino-h). 
Table 1. Detail of the field observations between 2012 and 2019.

\begin{tabular}{|c|c|c|c|}
\hline Date & $\begin{array}{l}\text { Observation Inside of the } \\
\text { Colony Shelter }\end{array}$ & $\begin{array}{c}\text { Observation Outside of } \\
\text { the Colony Shelter } \\
\text { (Emergence). } \\
\text { LT = Local Time }\end{array}$ & $\begin{array}{l}\text { Observations in } \\
\text { Other Tunnels }(\mathrm{T}) . \\
\text { Species ( }{ }^{\circ} \text { Bats) }\end{array}$ \\
\hline 21 January 2012 & Full colony & $\begin{array}{c}\text { Onset time }=19: 50 \mathrm{LT} \\
\text { Sunset time }=20: 22 \mathrm{LT} \\
\text { End time }=20: 35 \mathrm{LT}\end{array}$ & - \\
\hline 06 July 2012 & Without bats & - & T3 = Without bats \\
\hline 23 July 2012 & $500-1000$ bats & - & $\begin{array}{c}\mathrm{T} 5=\text { Desmodus rotundus } \\
\text { (small colony) }\end{array}$ \\
\hline 11 July 2013 & More than 500 bats & - & $\mathrm{T} 5=D$. rotundus $(10)$ \\
\hline 15 August 2013 & Without bats & - & $\mathrm{T} 5=$ D. rotundus $(15)$ \\
\hline 13 September 2013 & Without bats & - & $\begin{array}{c}\text { T3 = Histiotus sp. (9), } \\
\text { Myotis dinellii (1) } \\
\text { T4 = M. dinellii (2), } \\
\text { Tadarida brasiliensis (1) } \\
\text { T5 = D. rotundus (15) }\end{array}$ \\
\hline 24 October 2013 & $\begin{array}{l}\text { Full colony. Adults. Colony } \\
\text { size estimation }\end{array}$ & - & - \\
\hline 12 December 2013 & $\begin{array}{l}\text { Full colony. Adults } \\
\text { and newborns }\end{array}$ & $\begin{array}{c}\text { Onset time }=20: 35 \mathrm{LT} \\
\text { Sunset time }=20: 14 \mathrm{LT} \\
\text { End time }=21: 17 \mathrm{LT}\end{array}$ & - \\
\hline 27 January 2014 & $\begin{array}{l}\text { Full colony. Adults } \\
\text { and young }\end{array}$ & $\begin{aligned} \text { Onset time } & =20: 23 \mathrm{LT} \\
\text { End time } & =21: 27 \mathrm{LT}\end{aligned}$ & - \\
\hline 26 February 2014 & Full colony & - & $\begin{array}{c}\mathrm{T} 3=\text { Histiotus sp. (62), } \\
\text { M. dinellii (2) }\end{array}$ \\
\hline 13 March 2014 & Full colony & $\begin{array}{r}\text { Onset time }=19: 58 \mathrm{LT} \\
\text { Sunset time }=19: 35 \mathrm{LT} \\
\text { End time }=20: 40 \mathrm{LT} \\
\text { Onset time }=19: 45 \mathrm{LT}\end{array}$ & 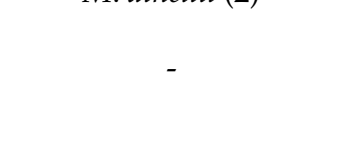 \\
\hline 26 March 2014 & Full colony & $\begin{array}{c}\text { Sunset time }=19: 19 \mathrm{LT} \\
\text { End time }=- \\
\text { Onset time }=19: 10 \mathrm{LT}\end{array}$ & - \\
\hline 15 April 2014 & Full colony & $\begin{array}{c}\text { Sunset time }=18: 55 \mathrm{LT} \\
\text { End time }=20: 00 \mathrm{LT}\end{array}$ & - \\
\hline 30 April 2014 & Full colony & - & - \\
\hline 13 May 2014 & $\begin{array}{l}\text { Partial colony } \\
\text { (less than } 25 \%)\end{array}$ & - & $\begin{array}{c}\mathrm{T} 3=\text { Histiotus sp. (2), } \\
\text { M. dinellii (1) }\end{array}$ \\
\hline 22 September 2014 & Full colony. Adults. & - & $\begin{array}{c}\mathrm{T} 3=\text { Histiotus sp. (1), } \\
\text { M. dinellii (1) }\end{array}$ \\
\hline 09 December 2014 & $\begin{array}{l}\text { Full colony. Adults } \\
\text { and young }\end{array}$ & $\begin{array}{c}\text { Onset time }=20: 30 \mathrm{LT} \\
\text { Sunset time }=20: 12 \mathrm{LT} \\
\text { End time }=-\end{array}$ & - \\
\hline 15 April 2015 & $\begin{array}{l}\text { Partial colony } \\
\text { (less than } 50 \%)\end{array}$ & - & - \\
\hline 05 May 2015 & $\begin{array}{l}\text { Partial colony } \\
\text { (less than } 25 \%)\end{array}$ & - & - \\
\hline 11 November 2016 & Full colony. Adults. & - & T3 = Histiotus sp. (40) \\
\hline 02 February 2017 & $\begin{array}{l}\text { Full colony. Adults } \\
\text { and young }\end{array}$ & - & $\begin{array}{c}\mathrm{T} 3=\text { Histiotus sp. } \\
\text { M. dinellii (1) }\end{array}$ \\
\hline 30 November 2017 & $\begin{array}{l}\text { Full colony. Adults } \\
\text { and newborns }\end{array}$ & _ & $\begin{array}{l}\mathrm{T} 3=\text { Histiotus sp. }(23) \\
\text { D. rotundus }(1)\end{array}$ \\
\hline 07 December 2018 & - & $\begin{array}{c}\text { Onset time }=20: 30 \mathrm{LT} \\
\text { Sunset time }=20: 11 \mathrm{LT} \\
\text { End time }=21: 35 \mathrm{LT}\end{array}$ & - \\
\hline 03 April 2019 & Full colony & - & - \\
\hline
\end{tabular}


The colony emerges massively as a continuous serpentine stream which borders the mountain (Figure $7 \mathrm{~g}, \mathrm{~h}$ ), and then, it becomes more diffuse, with less group integrity. The onset time of emergence was between 19:10 to 20:35 LT, starting 4 to 26 min after sunset except once being registered $32 \mathrm{~min}$ before sunset. The emergence lasts approximately $50 \mathrm{~min}$, a period of time in which different birds such as owls (Tyto alba), peregrine falcons (Falco peregrinus), and red falcons (Falco sparverius) are waiting for the emergence to hunt the bats. Table 1 shows the details of field observations and seasonal variations of the colony population and their composition are summarized in Figure 8.

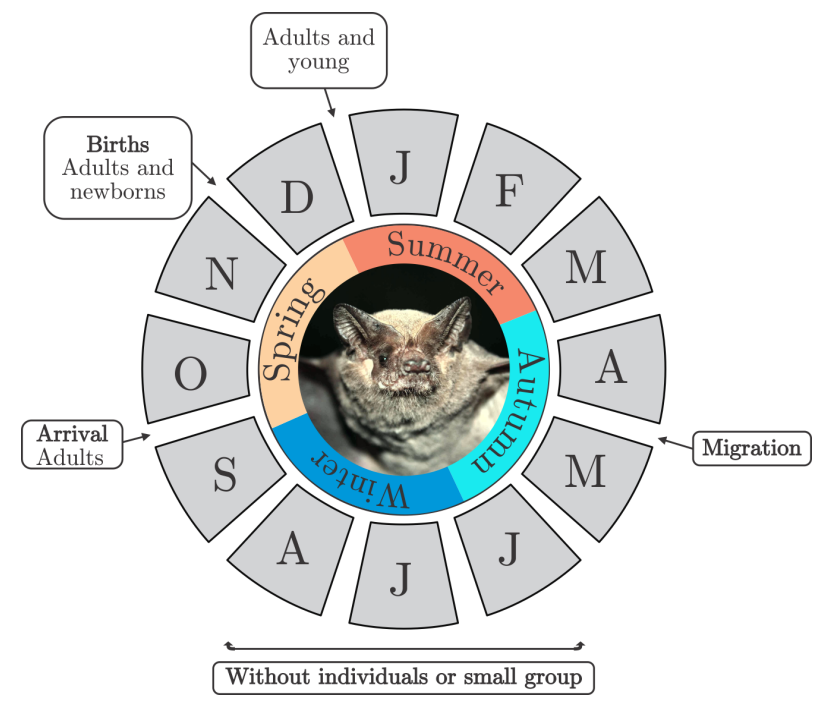

Figure 8. Activity cycle of the colony of T. brasiliensis through out the year. (Photo credits: R.M. Barquez).

\subsection{Radar Bat Detection}

To analyze the behavior of the bat colony located in La Calera, an analysis of RMA1 data was carried out from July 2018 to June 2019 in a two-hour interval, from 20 to 22:00 LT. An example of radar detection can be seen in Figure 9. This figure refers to the detection made on 7 December 2018, and shows that the emergence is recorded at 20:34 LT and continued throughout the sampling interval. The colors of the image refer to the echo intensity received by the targets (horizontal reflectivity factor $Z_{H}$ ) and show how the intensity and shape of the echo changes during the colony emergence. This factor refers to the echo intensity received by the radar being directly proportional to the size of the targets and the number of individuals $[29,40]$.

To achieve a record that allows daily monitoring of the colony, the maximum value of $Z_{V}$ is taken within the sampling area defined in Figure 3 and that value is labeled to see its temporal evolution, as can be seen in Figure 10. The data observed and processed are shown in an interval that goes from 1 December to 8 December 8 2018, between 20 to $22 \mathrm{~h}$ (LT).

A monthly follow-up can be carried out taking the maximum value of $Z_{V}$ of each daily observation, as shown in Figures 11 and 12. The first of these figures contains the months from July 2018 to December 2018 and shows that there is no activity of the colony during the winter months, while the activity begins in mid-September. The months of November and December show a consolidated activity around $30 \mathrm{dBZ}$. The second of these figures, Figure 12, shows the behavior from the months of January 2019 to the month of June 2019. The first four months of this figure show the same behavior as the last months of Figure 11, with an average of $Z_{V}$ that remains around $30 \mathrm{dBZ}$. This figure shows that the detection of the colony begins to decline from May to June. 


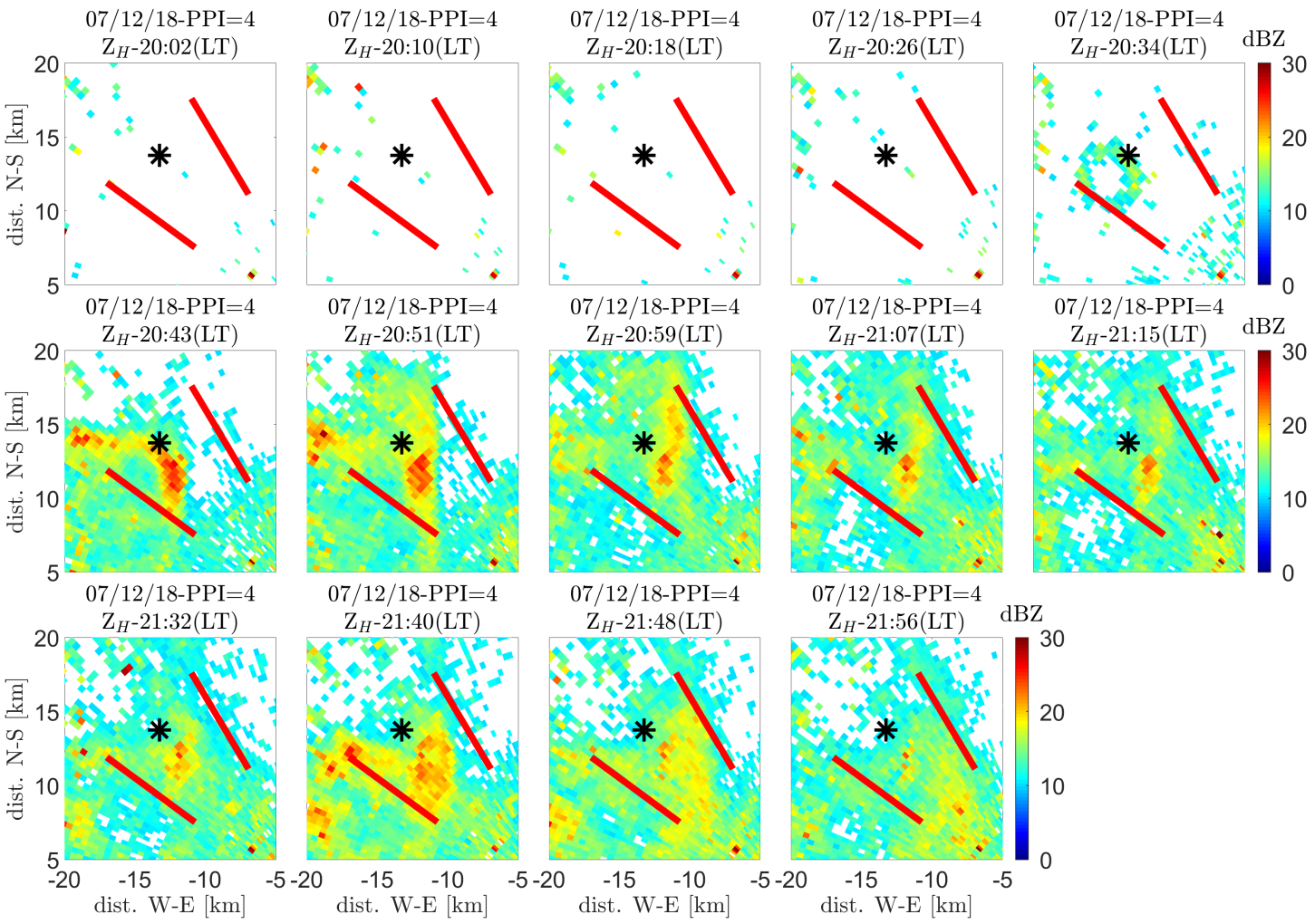

Figure 9. Temporal sequence of the horizontal reflectivity factor associated with the PPI 4 for 7 December 2018, between 20 to 22 LT.

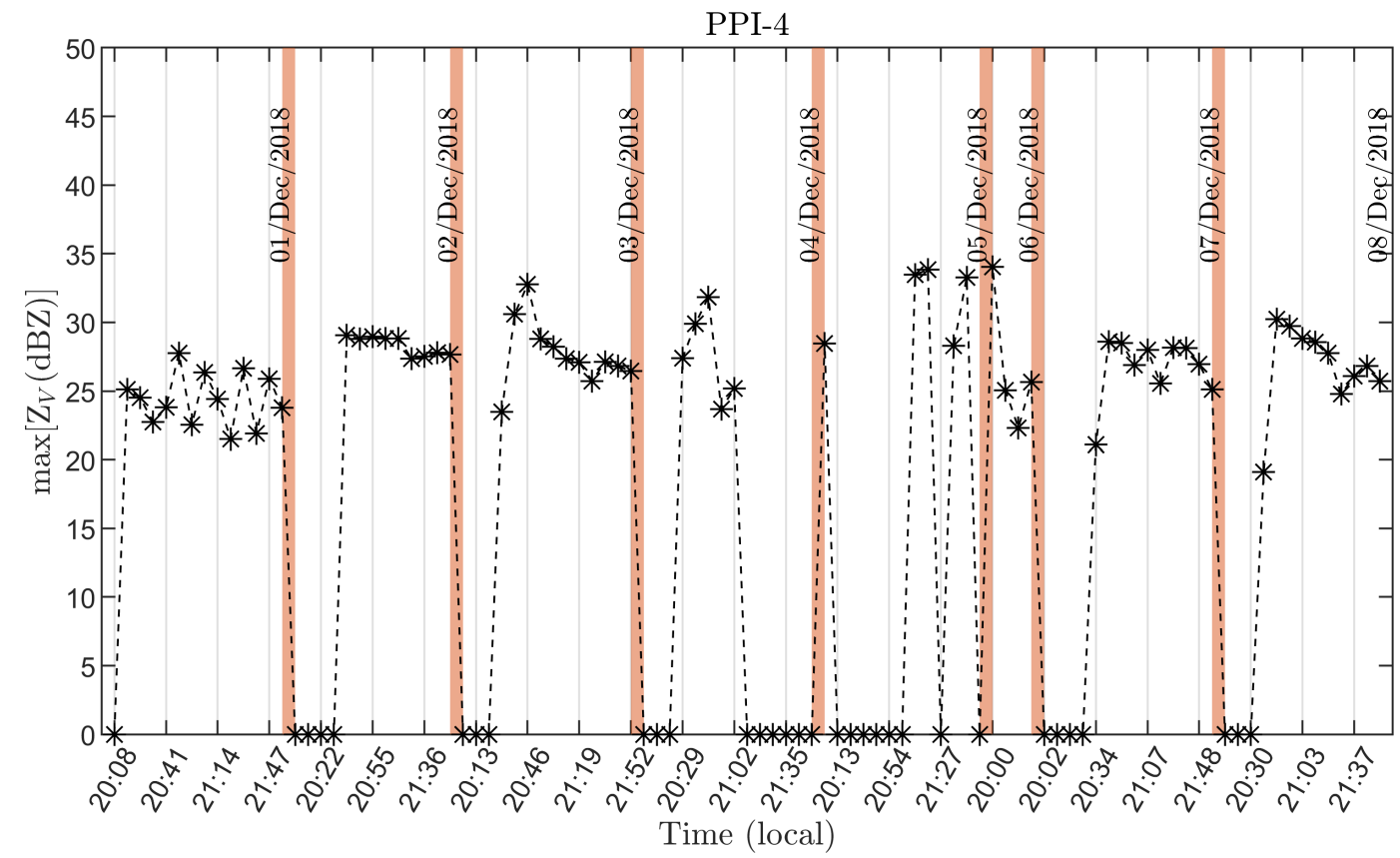

Figure 10. Maximum variability of $Z_{V}$ within the sampling interval between 1 December 2018, to 8 December 2018. 

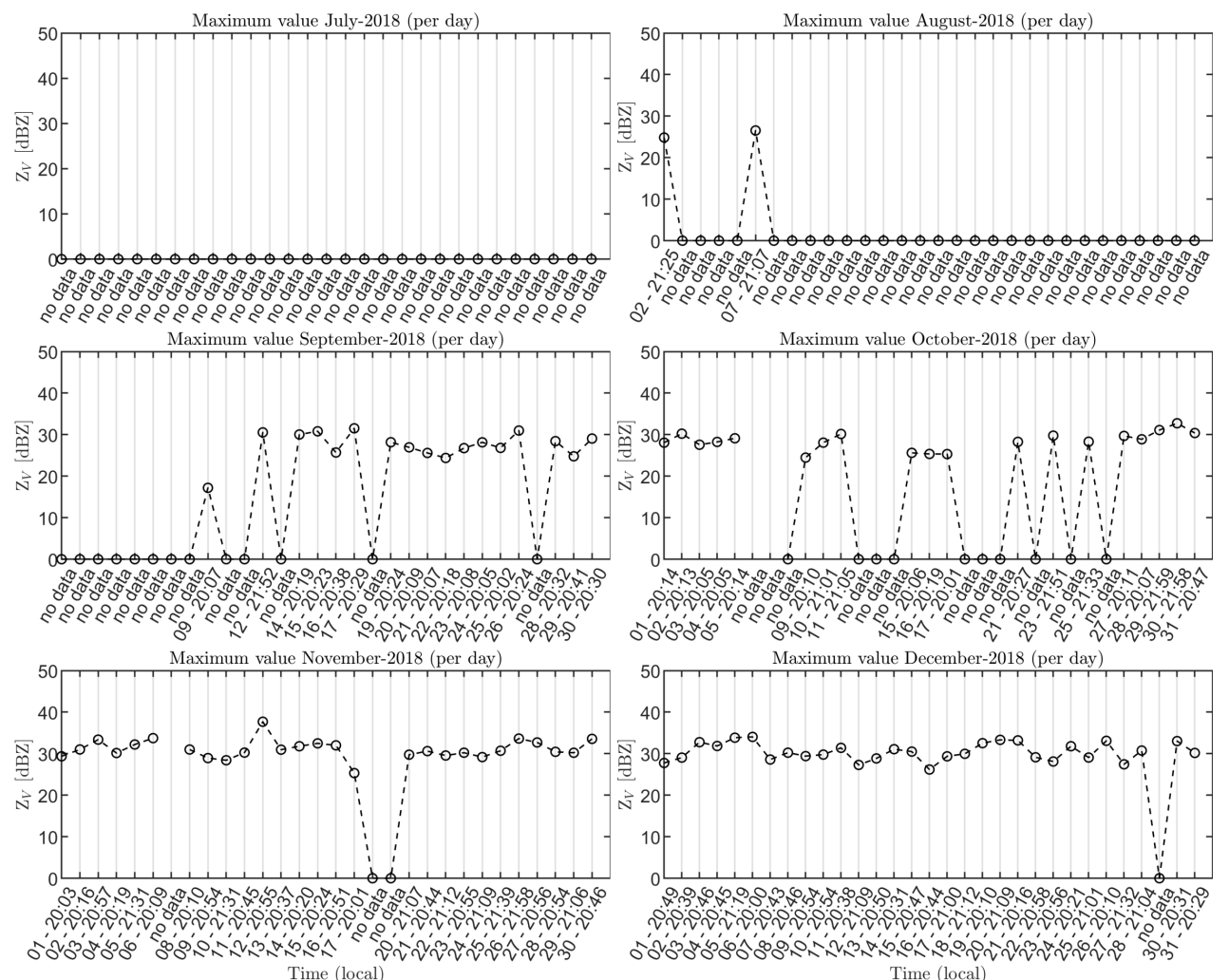

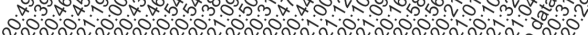

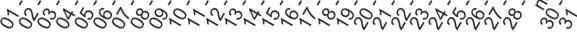
Time (local) Time (local)

Figure 11. Maximum value $Z_{V}$ reflectivity factor taken per day of observation. The registered period goes from July 2018 to December 2018.
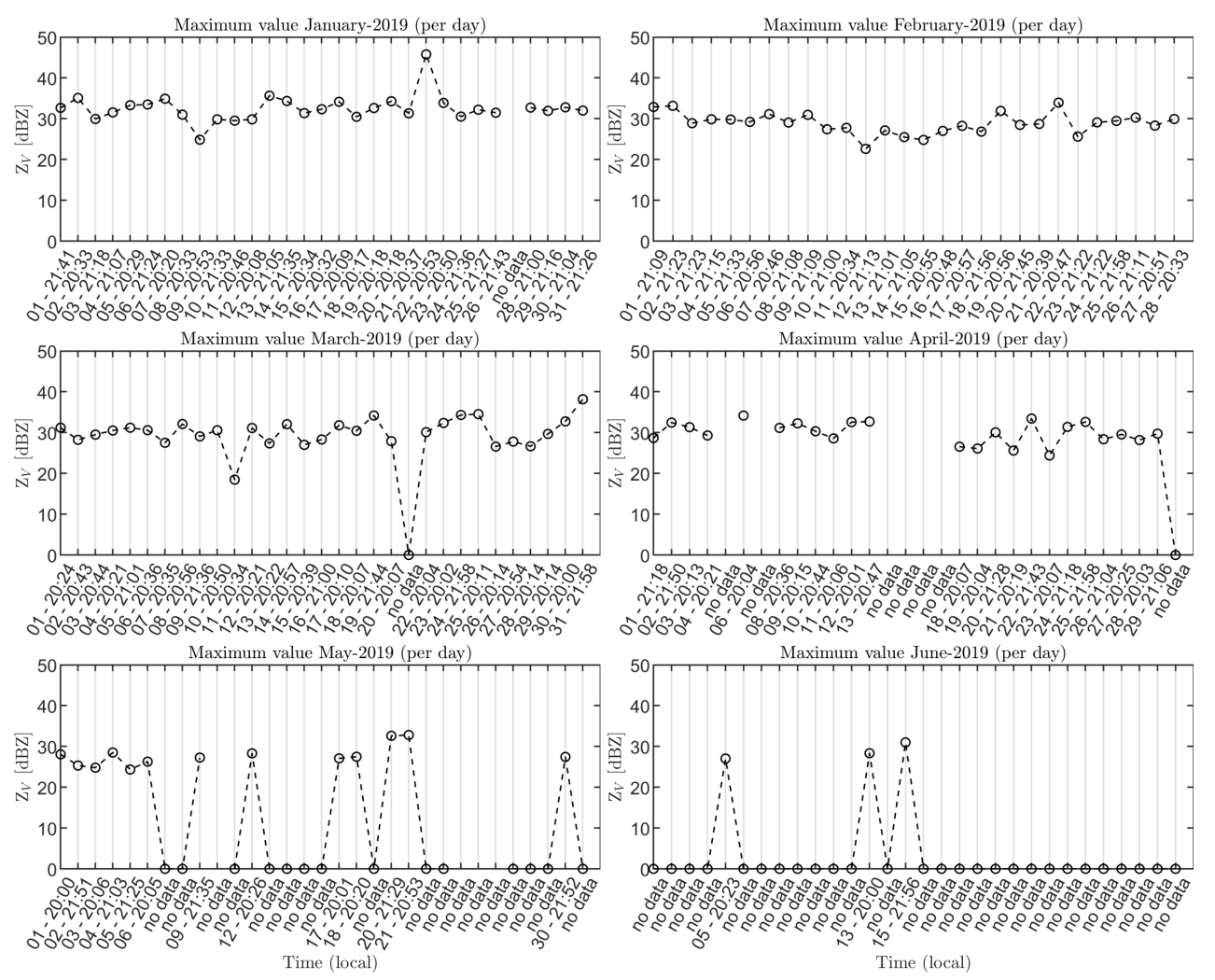

Figure 12. Maximum value $Z_{V}$ reflectivity factor taken per day of observation. The registered period goes from January 2019 to June 2019. 


\section{Discussion}

The large colony of Tadarida brasiliensis from La Calera roosts only in tunnel 2 but occasionally occupies part of tunnel 1. The other tunnels are occupied by Histiotus sp., Myotis dinellii, and Desmodus rotundus, which roost solitary or in small colonies [41]. It is known that shelters used by large colonies of $T$. brasiliensis are particular and have a large enough surface for millions of bats to hang, as well as spacious rooms, considerable height, and large entrances allowing a massive rate of emergence [14]. Also, this species seems to avoid wet shelters [14]. Tunnel 2 is the largest and has a large entrance (Figure 1c) that falls into a ravine without obstacles, unlike the entrance of tunnel 5, which is at the ground level and surrounded by vegetation. Moreover, tunnel 2 consists of a single large passage, unlike tunnel 4 which has subdivisions that interrupt the flow of bats. It also has less incidence of light than tunnel 3, and less humidity than tunnel 1, which has more water infiltration.

In South America, the largest known colony of T. brasiliensis is located at the Dam Escaba (Tucumán, Argentina), and is estimated in tens of millions of individuals, although it recently suffered a drastic decline [19,42] due to significant changes in the shelter with the argument of "relocating" the colony (see [43]). Another known large colony is present in the Law Faculty at Rosario (Santa Fé, Argentina), originally composed of 64,000 bats which roost in the ceiling of the building [17], but reduced to half after a fire in the building in 2003. Moreover, in Porto Alegre (Rio Grande do Sul state, Brazil) and several departments of Uruguay there are buildings which have colonies from 1000 to 10,000 individuals [20,44]. In La Calera we estimated 900,000 individuals in the colony, which allows us to confirm that is the second largest known colony known of T. brasiliensis in South America. Nevertheless, this estimation was performed before births occurred. For this reason, we believe that the colony is even larger if newborns and young are considered.

The colony of La Calera is maternal and migratory, as are others in South America and numerous in North America. These kind of colonies are only present in temperate zones, from $27^{\circ} \mathrm{S}$ to $31^{\circ} \mathrm{S}$ latitudes $[16,17,20,42]$ and $25^{\circ} \mathrm{N}$ to $38^{\circ} \mathrm{N}$ [35], despite the fact that $T$. brasiliensis is more widely distributed in America. The annual activity cycle of all these colonies are seasonally similar, with arrival to the shelters in early- to mid-spring, births in late spring, and migrations in late summer or early autumn, showing patterns of gradualness until the shelters are empty or just inhabited by a small group of individuals that remain during the cold seasons, as is shown in Figures 7, 8, 11, 12 and Table $1[15-18,20,30]$. There is no information about migratory routes in the South American colonies, unlike in North America where it is known that they migrate towards lower latitudes $[45,46]$, reaching distances of up to $1800 \mathrm{~km}$ [47]. These pulses of migrations in coordination with the reproduction of this species are associated with environmental factors and food availability [16,48].

Tadarida brasiliensis is known to be seasonal monoestrous $[49,50]$ with females giving birth to a single pup which, in the large maternal colonies, are placed in creches with thousands of other infants, while females roost separately [15-17]. We have observed these creches in La Calera (Figure 7c). The lactating females return to the creche twice a day to nurse [15], and are able to discriminate their own pup by means of location memory, pups vocalization, and olfactory cues [51,52]. On the other hand, observation on the growth of newborns in La Calera coincides with those reported for others colonies in both hemispheres, where the young of five to six weeks have hair, a size similar to that of adults, and already begin to fly $[15-17,48]$. Two weeks after the first flights, young bats are weaned and begin to emerge outside their shelters to satisfy their nutritional needs independently [53].

The massive emergence of the colonies of $T$. brasiliensis are either diffuse, where there is little group integrity, or serpentine, where the bats fly in a column [54]. In La Calera, most of the time the emergence was serpentine, contrary to what it was observed in several caves in Texas state (USA) [54] and in El Salitre cave, Hidalgo state (Mexico) [55]. The time of emergence is mainly correlated with the sunset, but also varied according to the energetic demands for reproduction of the cohort, differences in climate, and prey availability $[38,53]$. We observed that the onset time of emergence varied seasonally according the sunset. On the other hand, energy requirements could also influence onset time of emergence, i.e., the earliest emergence observed in January (Table 1) could be lactating females that, 
having higher energy demands, emerge earlier [53,56]. Numerous birds of prey take advantage of massive emergences of T. brasiliensis to hunt $[14,15]$, and the species observed around the colony of La Calera are known predators of $T$. brasiliensis $[17,57,58]$.

Detections made by RMA1 showed important similarities with those made in the field on the same day. In 7 December 2018, the time of emergence was at 20:30 LT (Figure 7g and Table 1) and the radar detection was at 20:34 LT (Figure 9 and Figure 10). At that moment, the intensity of the echo was lower (horizontal reflectivity factor $Z_{H}$ ) and more concentrated in the surrounding area of the shelter than in subsequent detections (Figure 9) when it became more intense and disperse. This could have happened because most of the bats emerged and dispersed out of the shelter. On the other hand, the end time of the emergence was registered at 21:35 LT, while the radar detection continued at 22:00 (final of sampling interval), where the intensity of the echo was more concentrated away from the shelter. The spatial pattern shown by the RMA1 could be explained by the foraging activity made by this species around $50 \mathrm{~km}$ [32]. Moreover, radar detections throughout the year agree with the activity cycle of the colony of T. brasiliensis obtained by field observations and with records for other similar colonies, in temperate zones from South and North America (mentioned above). True radar detections started in early-September, 2018 and remained continued until April 2019, coinciding with the observed periods of permanence of the colony. Despite the continuous detections during this period, some intermittence was shown, manly in October 2018. In the case of radar detections in May 2019, it was not possible to confirm whether the radar detected the colony that postponed its departure; or the small group that is usually find in that month (Table 1); or, if they are false detections, due to the lack of simultaneous field observation. For the same reason, in the isolated detections of August 2018 and June 2019, we cannot confirm if it is the small permanent group or false detections. With respect to the analysis using $Z_{d p}$, it agrees with the conceptual model proposed by Mirkovic et al., [33]. We also found negative values such as $\mathrm{Z}_{d r}$ during the emergence of the colony.

Large migratory and maternal colonies of $T$. brasiliensis must be a priority for conservation plans since they present potential threats and, at the same time, provide important ecosystem services [35,42,59]. Some threats for this species are mortality caused by wind turbines installed in their migration routes, as well as disturbances that alter the few shelters used by these large maternal colonies $[4,9,18,42,60]$. These colonies provide an important ecosystem service in the area within $50 \mathrm{~km}$ of the shelter [59]: one million lactating females of $T$. brasiliensis can consume eight tons of insects each night, including pest species of crops [4]. Currently, T. brasiliensis is a protected species by the Convention on the Conservation of Migratory Species of Wild Animals (CMS, Appendix I-Adheres National Law of Argentina 23,918). Added to this, based on proposals from PCMA (Programa de Conservación de Murciélagos de Argentina-Bat Conservation Program of Argentina), the three large colonies known in Argentina have been recognized as SICOMs (Sitio de Importancia para la Conservación de Murciélagos-Sites of Importance for Conservation of Bats), by the RELCOM (Red Latinoamericana para la Conservación de los Murciélagos-Latin American Bat Conservation Network) [61]. Particularly, the colony of La Calera and its habitats are protected by a Provincial Resolution (R-2541/12) [41]. Despite this legal protection, it is necessary to continue monitoring the colony in the long term to assess its conservation status and to alert for possible changes in the permanence of the colony or in the number of individuals. Radar technology is a very powerful tool to carry out this task [30] and, in this case, the RMA1 is reliable for monitoring the colony of La Calera.

\section{Conclusions}

The colony of T. brasiliensis present in La Calera represents the second largest known colony of bats in South America, with 900,000 individuals. We confirmed that this colony is maternal and migratory, as well as that it is present in the warm seasons and absent or reduced during cold seasons, similar to other large colonies detected in temperate areas of America. It was characterized using ecological and behavioral aspects related to the kind of shelter, presence of creches, growth of the 
newborn, emergence of the colony, and predators. It is important to reinforce and deepen all subjects included in this preliminary study.

The observations made by RMA1 show this instrument is not only useful for meteorological detection but also for biological targets. Detection of an emergence was proven to be accurate as compared with simultaneous field observations. Also, the observation made by this radar agree with field observations when the activity cycle of the colony of T. brasiliensis through the year is considered. The algorithm generated to determine if a detection is a true or a false emergence of bats was consistent, most of the time, with what was expected according to field observations. However, this needs to be checked with more simultaneous field observations because there are some false detections during the period of permanence and some true detections during the period in which the colony is absent or markedly reduced. For this reason, we consider that more years of analyses with the inclusion of statistical analysis are needed.

This represents, to our knowledge, the first study made in South America using field observations together with radar technology to obtain complete information about a bat colony. We here demonstrate that RMA1 can be a powerful tool for monitoring a colony at a long term, and even to alert possible changes in the permanence of the colony or the number of individuals. This monitoring would allow researchers to reinforce the conservation strategies for the colony. Moreover, this is an initial step to stimulate further studies which may allow scientists to know which variables determine the daily activity pattern (onset time of the emergence and return), as well as the annual activity cycle (permanence and migrations), estimate the population number through radar data, and to have a better knowledge about the ecosystem service provided by the colony to the surrounding farmers.

Author Contributions: Conceptualization, L.B., D.P., V.D., S.V. and H.M.B.; methodology, L.B., D.P., V.D. and S.V.; software, D.P., M.S. and A.R.; validation, L.B., V.D., S.V., D.P.; formal analysis, L.B., D.P., V.D. and S.V.; investigation, L.B., D.P., V.D., S.V., R.M.B., A.R., M.S. and H.M.B.; resources, R.M.B., A.R., and H.M.B.; writing-original draft preparation, L.B., D.P., V.D., S.V. and H.M.B.; writing-review and editing, L.B., D.P., V.D., S.V., R.M.B., A.R., M.S. and H.M.B.; visualization, L.B., D.P., V.D., S.V., R.M.B., A.R., M.S. and H.M.B.; supervision, L.B., D.P., V.D., S.V., R.M.B. and H.M.B.; project administration, L.B., D.P., V.D., S.V., R.M.B., A.R., M.S. and H.M.B.; funding acquisition, A.R. and H.M.B. All authors have read and agreed to the published version of the manuscript.

Funding: This research was funded by Secretaría de Ciencia y Tecnología, Universidad Nacional de Córdoba: PIP 33820180100357CB and PIP 33620180100692CB.

Acknowledgments: We are grateful to Cantera Dumesnil S.A. for allowing us to carry out this study within the property, to SiNaRaMe (Sistema Nacional de Radares Meteorológicos) for authorizing access to the data of the RMA1. We are also grateful to Secretaría de Ciencia y Tecnología (SECyT-UNC) to its helps and to Raúl Comes for reading and correcting the manuscript.

Conflicts of Interest: The authors declare no conflict of interest.

\section{References}

1. Moore, F.; Gauthreaux, S.A.J.; Kerlinger, P.; Simons, T.R. Habitat requirements during migration: Important link in conservation. In Ecology and Management of Neotropical Migratory Birds; a Synthesis and Review of Critical Issues; Martin, T.E., Finch, D.M., Eds.; Oxford University Press: New York, NY, USA, 1995; pp. 121-144.

2. Chilson, P.B.; Frick, W.F.; Kelly, J.F.; Howard, K.W.; Larkin, R.P.; Diehl, R.H.; Westbrook, J.K.; Kelly, T.A.; Kunz, T.H. Partly cloudy with a chance of migration: weather, radars, and aeroecology. Bull. Ame. Meteorol. Soc. 2012, 93, 669-686. [CrossRef]

3. Loss, S.R.; Will, T.; Marra, P.P. Estimates of bird collision mortality at wind facilities in the contiguous United States. Biol. Conserv. 2013, 168, 201-209. [CrossRef]

4. Kunz, T.H.; de Torrez, E.B.; Bauer, D.; Lobova, T.; Fleming, T.H. Ecosystem services provided by bats. Ann. N. Y. Acad. Sci. 2011, 1223, 1-38. [CrossRef] [PubMed]

5. Boyles, J.G.; Cryan, P.M.; McCracken, G.F.; Kunz, T.H. Economic importance of bats in agriculture. Science 2011, 332, 41-42. [CrossRef] [PubMed]

6. Voigt, C.C.; Kingston, T. Bats in the Anthropocene. In Bats in the Anthropocene: Conservation of Bats in a Changing World; Voigt, C.C., Kingston, T., Eds.; Springer: Cham, Switzerland, 2016; pp. 1-9 . 
7. Jones, G.; Jacobs, D.S.; Kunz, T.H.; Willig, M.R.; Racey, P.A. Carpe noctem: the importance of bats as bioindicators. Endanger. Species Res. 2009, 8, 93-115. [CrossRef]

8. Aguirre, L.F.; Medellín, R.A.; Rodríguez-Herrera, B. From threat to opportunity. In Tropical Conservation: Perspectives on Local and Global Priorities, 1st ed.; Aguirre, A.A., Sukumar R., Eds.; Oxford University Press: New York, NY, USA, 2016; pp. 140-153.

9. O'shea, T.J.; Cryan, P.M.; Hayman, D.T.; Plowright, R.K.; Streicker, D.G. Multiple mortality events in bats: A global review. Mammal Rev. 2016, 46, 175-190. [CrossRef] [PubMed]

10. Schneeberger, K.; Voigt, C.C. Zoonotic viruses and conservation of bats. In Bats in The Anthropocene: Conservation of Bats in a Changing World; Springer: Cham, Switzerland, 2016; pp. 263-292.

11. Simmons, N.B. An Eocene big bang for bats. Science 2005, 307, 527-528. [CrossRef]

12. Barquez, R.M.; Carbajal, M.N.; Failla, M.; Díaz, M.M. New distributional records for bats of the Argentine Patagonia and the southernmost known record for a molossid bat in the world. Mammalia 2013, 77, 119-126. [CrossRef]

13. Cleveland, C.J.; Betke, M.; Federico, P.; Frank, J.D.; Hallam, T.G.; Horn, J.; Lopez, J.D., Jr.; McCracken, G.F.; Medellín, R.A.; Moreno-Valdez, A.; et al. Economic value of the pest control service provided by Brazilian free-tailed bats in south-central Texas. Front. Ecol. Environ. 2006, 4, 238-243. [CrossRef]

14. Wilkins, K.T. Tadarida brasiliensis; Mamm. Species; 1989; pp. 1-10.

15. Davis, R.B.; Herreid, C.F.; Short, H.L. Mexican free-tailed bats in Texas. Ecol. Monogr. 1962, 32, 311-346. [CrossRef]

16. Fabian, M.E.; Marques, R. Aspectos do comportamento de Tadarida brasiliensis brasiliensis (I. Geoffroy, 1824) (Chiroptera, Molossidae) em ambiente urbano. Biociências 1996, 4, 65-86.

17. Romano, M.C.; Maidagan, J.I.; Pire, E.F. Behavior and demography in an urban colony of Tadarida brasiliensis (Chiroptera: Molossidae) in Rosario, Argentina. Rev. Biol. Trop. 1999, 47, 1121-1127.

18. McCracken, G. Estimates of population sizes in summer colonies of Brazilian free-tailed bats (Tadarida brasiliensis). In Monitoring Trends in Bat Populations of the US and Territories: Problems and Prospects; Biological Resources Discipline, Information and Technology Report, USGS/BRD/ITR-2003-003; O'Shea, T.J., Bogan, M.A., Eds.; United States Geological Survey: Reston, VA, USA, 2003; pp. 21-30.

19. Gamboa Alurralde, S.; Barquez, R.M.; Díaz, M.M. New records of bats (Mammalia: Chiroptera) for a southern locality of the Argentine Yungas. Check List 2017, 13, 2105. [CrossRef]

20. Botto Nuñez, G.; Genta, M.; Díaz, M.; Rodales, A.L.; González, E.M. Circannual sex distribution of the Brazilian free-tailed bat, Tadarida brasiliensis (Chiroptera: Molosssidae), suggests migration in colonies from Uruguay. Mastozool. Neotrop. 2018, 25, 213-219. [CrossRef]

21. Russell, A.L.; McCracken, G.F. Population genetic structuring of very large populations: The Brazilian free-tailed bat Tadarida brasiliensis. In Functional and Evolutionary Ecology of Bats; Akbar, Z., McCracken, G.F., Kunz, T.H., Eds.; University Press: New York, NY, USA, 2006; pp. 227-247.

22. Chilson, P.B.; Frick, W.F.; Stepanian, P.M.; Shipley, J.R.; Kunz, T.H.; Kelly, J.F. Estimating animal densities in the aerosphere using weather radar: To Z or not to Z? Ecosphere 2012, 3, 1-19. [CrossRef]

23. Chilson, P.B.; Bridge, E.; Frick, W.F.; Chapman, J.W.; Kelly, J.F. Radar Aeroecology: Exploring the Movements of Aerial Fauna through Radio-Wave Remote Sensing. Biol. Lett. 2012, 8, 698-701. [CrossRef]

24. Bruderer, B. Three decades of tracking radar studies on bird migration in Europe and the Middle East. In Proceedings of the International Seminar on Birds and Flight Safety in the Middle East, Tel-Aviv, Israel, 25-29 April 1999; Leshem, Y., Mandelik, Y., Shamoun-Baranes, J., Eds.; Tel Aviv University: Tel Aviv, Israel, 1999; pp. 107-141.

25. Gauthreaux, S.A., Jr.; Livingston, J.W.; Belser, C.G. Detection and discrimination of fauna in the aerosphere using Doppler weather surveillance radar. Integr. Comp. Biol. 2008, 48, 12-23. [CrossRef]

26. Horn, J.W.; Kunz, T.H. Analyzing NEXRAD doppler radar images to assess nightly dispersal patterns and population trends in Brazilian free-tailed bats (Tadarida brasiliensis). Integr. Comp. Biol. 2008, 48, 24-39. [CrossRef]

27. Bonter, D.N.; Gauthreaux, S.A., Jr.; Donovan, T.M. Characteristics of important stopover locations for migrating birds: Remote sensing with radar in the Great Lakes basin. Conserv. Biol. 2009, 23, 440-448. [CrossRef]

28. Chapman, J.W.; Drake, V.A.; Reynolds, D.R. Recent insights from radar studies of insect flight. Annu. Rev. Entomol. 2011, 56, 337-356. [CrossRef] 
29. Poffo, D.A.; Beccacece, H.M.; Caranti, G.M.; Comes, R.A.; Drewniak, M.E.; Martina, A.; Zapata, A.I.; Rodriguez, A.; Saffe, J.N. Migration monitoring of Ascia monuste (Lepidoptera) and Schistocerca cancellata (Orthoptera) in Argentina using RMA1 weather radar. ISPRS J. Photogramm. Remote Sens. 2018, 145, 340-348. [CrossRef]

30. Stepanian, P.M.; Wainwright, C.E. Ongoing changes in migration phenology and winter residency at Bracken Bat Cave. Glob. Chang. Biol. 2018, 24, 3266-3275. [CrossRef]

31. Hüppop, O.; Ciach, M.; Diehl, R.; Reynolds, D.R.; Stepanian, P.M.; Menz, M.H. Perspectives and challenges for the use of radar in biological conservation. Ecography 2019, 42, 912-930. [CrossRef]

32. Williams, T.C.; Ireland, L.C.; Williams, J.M. High altitude flights of the free-tailed bat, Tadarida brasiliensis, observed with radar. J. Mammal. 1973, 54, 807-821. [CrossRef]

33. Mirkovic, D.; Stepanian, P.M.; Kelly, J.F.; Chilson, P.B. Electromagnetic model reliably predicts radar scattering characteristics of airborne organisms. Sci. Rep. 2016, 6, 35637. [CrossRef] [PubMed]

34. McCracken, G.F.; Gillam, E.H.; Westbrook, J.K.; Lee, Y.F.; Jensen, M.L.; Balsley, B.B. Brazilian free-tailed bats (Tadarida brasiliensis: Molossidae, Chiroptera) at high altitude: links to migratory insect populations. Integr. Comp. Biol. 2008, 48, 107-118. [CrossRef]

35. Wiederholt, R.; López-Hoffman, L.; Svancara, C.; McCracken, G.; Thogmartin, W.; Diffendorfer, J.E.; Mattson, B.; Bagstad, K.; Cryan, P.; Russell, A.; et al. Optimizing conservation strategies for Mexican free-tailed bats: A population viability and ecosystem services approach. Biodivers. Conserv. 2015, 24, 63-82. [CrossRef]

36. Burkart, R.; Bárbaro, O.; Sanchez, R.; Gómez, D. Ecorregiones de la Argentina; Administración de Parques Nacionales y Secretaria de Recursos Naturales y Desarrollo Sustentable: Buenos Aires, Argentina, 1999; pp. 1-43.

37. Barquez, R.M.; Díaz, M.M. Los Murciélagos de Argentina: Clave de Identificación; Publicación Especial 1 PCMA (Programa de Conservación de Murciélagos de Argentina), Ediciones Magna: Tucumán, Argentina, 2009; pp. 1-84.

38. Lee, Y.F.; McCracken, G.F. Timing and variation in the emergence and return of Mexican free-tailed bats, Tadarida brasiliensis mexicana (Molossidae). Zool. Stud. 2001, 9, 309-316.

39. Rauber, R.M.; Nesbitt, S.W. Radar Meteorology: A First Course, 1st ed.; Wiley Blackwell: Hoboken, NY, USA, 2018; pp. 1-488.

40. Poffo, D.A.; Caranti, G.M.; Comes, R.A.; Rodriguez, A. A new ash concentration estimation method using polarimetric data: The RMA observation of the 2015 Calbuco eruption. Remote Sens. Appl. Soc. Environ. 2019, 13, 224-233. [CrossRef]

41. Damino, V. Orden Chiroptera. In Mamíferos de Córdoba y su Estado de Conservación, 1st ed.; Torres, R., Tamburini, D., Eds.; Editorial de la UNC: Córdoba, Argentina, 2018; pp. 226-270.

42. Díaz, M.M.; Carbajal, M.; Lipps, E.; Lutz, M.A.; Rosenfeld, S.; Barquez, R.M. El estado de conservación de los murciélagos de Argentina. In Manejo de Fauna Silvestre en la ArgentinaArgentina, Programas de Conservación de Especies Amenazadas; Porini, G., Ramadori, D., Eds.; Dirección de Fauna Silvestre, Secretaría de Ambiente y Desarrollo Sustentable de la Nación: Buenos Aires, Argentina, 2013; pp. 273-281.

43. Regidor, H.; Mosa, S.; Núñez, A. Confinamento de una colonia de Tadarida brasiliensis, una alternativa de manejo compatible con la conservación. Chiropt. Neotrop. 2003, 9, 157-162.

44. Pacheco, S.M.; Sodré, M.; Gama, A.; Bredt, A.; Cavallini, E.M.; Marques, R.V.; Guimarães, M.; Bianconi, G. Morcegos urbanos: Status do conhecimento e plano de ação para a conservação no Brasil. Chiropt. Neotrop. 2010, 16, 629-647.

45. Villa, B.R.; Cockrum, E.L. Migration in the guano bat Tadarida brasiliensis mexicana (Saussure). J. Mammal. 1962, 43, 43-64.

46. Cockrum, E.L. Migration in the Guano Bat, Tadarida brasiliensis; University of Arizona Department of Biological Sciences: Tucson, AZ, USA, 1969.

47. Glass, B.P. Seasonal movements of Mexican freetail bats Tadarida brasiliensis mexicana banded in the Great Plains. Southwest. Nat. 1982, 27, 127-133. [CrossRef]

48. Kunz, T.H.; Robson, S.K. Postnatal growth and development in the Mexican free-tailed bat (Tadarida brasiliensis mexicana): Birth size, growth rates, and age estimation. J. Mammal. 1995, 76, 769-783. [CrossRef]

49. Blanco, A.; Gutierrez, M.; de Henquin, C.G.; de Burgos, N.M. Testicular lactate dehydrogenase isozyme: Cyclic appearance in bats. Science 1969, 164, 835-836. [CrossRef] [PubMed] 
50. Krutzsch, P.H.; Fleming, T.H.; Crichton, E.G. Reproductive biology of male Mexican free-tailed bats (Tadarida brasiliensis mexicana). J. Mammal. 2002, 83, 489-500. [CrossRef]

51. Gustin, M.K.; McCracken, G.F. Scent recognition between females and pups in the bat Tadarida brasiliensis mexicana. Anim. Behav. 1987, 35, 13-19. [CrossRef]

52. Gelfand, D.L.; McCracken, G.F. Individual variation in the isolation calls of Mexican free-tailed bat pups (Tadarida brasiliensis mexicana). Anim. Behav. 1986, 34, 1078-1086. [CrossRef]

53. Reichard, J.D.; Gonzalez, L.E.; Casey, C.M.; Allen, L.C.; Hristov, N.I.; Kunz, T.H. Evening emergence behavior and seasonal dynamics in large colonies of Brazilian free-tailed bats. J. Mammal. 2009, 90, 1478-1486. [CrossRef]

54. Herreid, C.F.; Davis, R.B. Flight patterns of bats. J. Mammal. 1966, 47, 78-86. [CrossRef]

55. López-Vidal, J.; Elizalde-Arellano, C.; Arroyo-Cabrales, J.; Medellín, R. Observaciones sobre movimientos y comportamiento de Tadarida brasiliensis mexicana en la cueva El Salitre, Meztitlán, Hidalgo, México. In Avances en el Estudio de los Mamíferos de México II, 1st ed.; Lorenzo, C., Espinoza, E., Ortega, J., Eds.; Sociación Mexicana de Mastozoología: Ciudad de México, México, 2008; pp. 615-634.

56. Kunz, T.; Oftedal, O.; Robson, S.; Kretzmann, M.; Kirk, C. Changes in milk composition during lactation in three species of insectivorous bats. J. Comp. Physiol. B 1995, 164, 543-551. [CrossRef] [PubMed]

57. Lee, Y.F.; Kuo, Y.M. Predation on Mexican free-tailed bats by peregrine falcons and red-tailed hawks. J. Raptor Res. 2001, 35, 115-123.

58. Rodríguez-San Pedro, A.; Allendes, J.L. Depredación del murciélago de cola libre Tadarida brasiliensis (I. Geoffroy Saint Hilaire, 1824) por el cernícalo Falco sparverius Linnaeus, 1758, en un sector urbano de Santiago, Región Metropolitana, Chile. Biodivers. Nat. History 2015, 1, 6-8.

59. Medellin, R.A.; Wiederholt, R.; Lopez-Hoffman, L. Conservation relevance of bat caves for biodiversity and ecosystem services. Biol. Conserv. 2017, 211, 45-50. [CrossRef]

60. Arnett, E.B.; Baerwald, E.F. Impacts of wind energy development on bats: Implications for conservation. In Bat Evolution, Ecology, and Conservation; Adams, R.A., Pedersen, S.C., Eds.; Springer: New York, NY, USA, 2013; pp. 435-456.

61. Aguirre, L.F.; Barquez, R.M. Critical areas for bat conservation: Latin American conservationists build a grand strategy. Bats 2013, 31, 10-12.

(C) 2020 by the authors. Licensee MDPI, Basel, Switzerland. This article is an open access article distributed under the terms and conditions of the Creative Commons Attribution (CC BY) license (http:/ / creativecommons.org/licenses/by/4.0/). 